$\mathbb{T}$ periodica polytechnica

\author{
Social and Management Sciences \\ $16 / 2(2008) 63 \quad 69$ \\ doi: 10.3311/pp.so.2008-2.02 \\ web: http://www.pp.bme.hu/so \\ (c) Periodica Polytechnica 2008
}

RESEARCH ARTICLE

\section{Short theoretic summary of the M\&A activity and overview of the trends in Hungary from 2002 to 2008}

\author{
Kornél Halmos
}

Received 2009-07-09

\begin{abstract}
Since 1989 the mergers and acquisitions have had great influence on the Hungarian economy. After the decline in the early 2000s the level of the M\&A activity became higher, but the composition of the deal types and driving forces changed.This study makes an attempt to identify the new trends of the M\&A figures in Hungary and to address the greatest problems in this field of research, the imperfect data and the traceable inconsistencies.

The results show high level of concentration of the deals in the origination of the buyers and in case of value of the deals. After 2006 the minority stake purchase became more significant through high value „mega-deals”.
\end{abstract}

\section{Keywords}

mergers $\cdot$ acquisitions $\cdot$ trends
Department of Economics, Faculty of Economic and Social Sciences, BME, H1111 Budapest, Múegyetem rkp. 3-9., Hungary

e-mail: halmos.kornel@gmail.com

\section{Introduction}

As long as in the developed countries the mergers and acquisitions have been an essential part of the inter-company relations such kind of legal actions in the Central European states were only possible after 1989 . Therefore studying the area covers only a shorter period of time. After a significant FDI inflow in the middle of the 1990s the topic gets to the central point of the research. The main determinant factors and effects were exhaustively examined. After 2000 the emphasis of the research was off-centered, but recently the M\&A market broke out of stagnation and from 2007 regained its strength. This study makes an attempt to identify the new trends on the M\&A figures in Hungary and to address the greatest problem in this field of research, the imperfect data and the traceable inconsistencies.

\section{The three basic types of mergers and acquisi- tions: [1]}

1 Horizontal fusion: two competitor firms from the same industrial sector merge, for example two service companies. This needs the closest cooperation between the participating companies, therefore the intensity of the resource transfer is the most vigorous in this case. Through accessing unique resources, capabilities and economics of scale factors the horizontal fusion can ensure monopolistic advantages.

2 Vertical fusion: fusion between two companies from the same industry. Forward vertical fusion if a corporation merge with its buyer, backward vertical fusion if the object of the merger is one of the suppliers of the firm. The resource transfer is intensive along the value-add process.

3 Conglomerate fusion: merger of two or more companies from different areas. Collaboration consists of mainly financial questions.

The motivation base of the M\&As is various and wideranging. For deeper understanding it is essential to sum up the theories regarding the formation of the mergers and acquisitions. 


\section{Main motivators of the M\&A}

\subsection{Theoretical approach}

1 Effectiveness theories:

(a) Different leading efficiency theory: when companies have different leading efficiency, the managers of the more efficiently leaded firm influence the less efficient organization in a positive way. Through this sinergy effect the organization can realize value. It encourages companies to merge with more effective competitors. These M\&As are typically horizontal, because similar firms can make profit of the specific managerial processes [2].

(b) Uneffective leading theory: in connection with the previous theory it says that companies with uneffective processes and management capabilities become a buy up target for an effective firm, because the more effective company sees good development opportunities in value boosting. In this case the business intelligence services play key role [1].

(c) Strategic alignment hypothesis: as a response to the transformed enviromental conditions the company would like to get hold of new resources.

(d) Clean diversification theory: [3] the larger company size makes the firm less vulnerable so it is worth to diversify. The M\&A is good for the employees and for the managers too, because they own a lot of special knowledge that is usable only inside the company. Further advantages higher stability, workplace security and higher salary can be mentioned.

\section{Share value based theories:}

The advantage of the market based approach are that it can analyse in parallel the propriatery value-addition process and the macro effects. Weaknesses come from the same approach as they can not reveal the origin of the synergies so only the consequences are analysed [4].

a) Undervaluation theory: if a company does not operate in a value maximizing way, the share price falls under the level of the substitution cost of the assets. The stock market undervalues it and through an acquisition a contractor can realize value.

b) Free cash-flow theory: based on this theory the engine of the M\&As is that the company has unused free cash-flow, which could be utilized efficiently. In this approach the free cash-flow is the excess money what the company cannot invest into a project with positive net present value [5]. Typical examples are firms after the peak of their life cycles with high cash generation potential but lack of growth potential.

\section{c) Consequences of agent theories [6]:}

The agency cost theory of mergers states that takeover activity often results from acquiring firm managers' acting in their own self-interests rather than in the interests of the firm's owners [7], Managers may be motivated to increase their compensation by increasing the size of the firm through non-value enhancing mergers or engaging in "expense preference" behavior by over-consumption of prerequisites [8]. Managers also may intentionally acquire businesses that require their personal skills in order to make it costly for the shareholders to replace them. To the extent that M\&As are primarily motivated by managerial self interest, they are unlikely to generate operating or financial synergies that lead to improvements of efficiency or productivity.

\subsection{Empirical approach:}

The motivations for takeover activities are divided into two parts, first when the company independent factors are the engines of the acquisition, second when internal factors are the main drivers. If M\&As are motivated by opportunities to improve performance and if managers succeed in accomplishing their objectives, efficiency or productivity should improve. If M\&As are motivated by non-value-enhancing factors or if postmerger integration is unsuccessful, then the merger activity may lead to deterioration of efficiency or productivity [9].

\subsubsection{External factors}

1 Regulatory and macroeconomic changes: Changes in antitrust regulations or in input-output costs often lead to overheated M\&A activity. Based on the World Investment Report 2004[10] during the late 1990s M\&A favouring regulation changes were effected followed by the most intensive M\&A activity, until the backlash of anti-trust questions became too strong.

Regarding the effect of legal and regulatory stability, Rossi and Volpin [11] find that the volume of M\&A activity is significantly larger in countries with better accounting standards and stronger shareholder protection. The probability of an all-cash bid decreases with the level of shareholder protection in the acquirer country. In cross-border deals, targets are typically from countries with poorer investor protection than their acquirers' countries, suggesting that cross-border transactions play a governance role by improving the level of investor protection within target firms.

2 Industrial shocks and consolidation processes Industry shock theory says that M\&A activities within an industry are not merely firm-specific phenomena but the result of the adaptation of industry structure to a changing economic environment or industry shocks such as the followings:

- increased foreign or domestic competition,

- innovations in technology.

Corporate takeovers are the least costly means for an industry to restructure in response to the changes brought about by economic shocks, but the post-takeover performance of 
firms should not necessarily improve, compared to a preshock benchmark [12].

3 Company size: Firms with smaller size, relatively low growth prospects, higher insolvency risk, or vulnerable capital structures are less able to benefit from the industry's overall prosperity and are vulnerable to takeover by stronger firms. As a consequence of this, financially vulnerable firms are more likely to become takeover targets. The efficiency of target firms will not necessarily improve if these acquisitions are linked to an industry shock to the target or acquirers.

\subsubsection{Internal factors}

\section{Economies of scale and economies of scope}

The most frequently cited reason for a takeover is economies of scale - firms expand to obtain optimal operating scale and thereby reduce average unit costs of production. The usual source of cost scale economies is the spreading of fixed costs over a broader output base.

If mergers permit firms to realize scale economies, the performance of the target and acquirer will improve after the transactions. There is no special reason to believe that acquirers will be scale efficient. Size is an advantage for an acquirer, and many large firms are not scale efficient.

Achieving economies of scope is another motivation often attributed to M\&A transactions. Cost scope economies can arise if a firm can reduce overall production costs by providing different types of products, rather than specializing. Examples include gains from exploiting shared resources such as customer lists, brand names, managerial talent, information technology, or customer service capabilities. Revenue economies of scope arise if customers prefer to deal with firms that provide several types of financial services due to reduced search costs and other factors that create preferences for "one-stop shopping." If a merger or an acquisiton enable firms to achieve economies of scope, mergers that result in increased geographical or product line diversification are expected to lead to higher efficiency or productivity gains.

\section{Financial synergies}

The other main motivator of the mergers and acquisitions are the financial synergies. Financial synergy theory stakes that, with asymmetric information in financial markets, a firm with insufficient liquid assets or financial slack may not exploit all valuable investment opportunities. In this case, the firm can increase its value by merging with an asset-rich firm if the information asymmetry between the two firms is smaller than that between the asset-poor firm and outside investors. Thus, takeover may be an efficient means to ease information asymmetries and achieve financial synergies. This theory predicts that firms in financial distress but with good investment opportunities are more likely to be involved in M\&A activities, either as targets or as acquirers.

\section{Leadership motivations 13}

Corporate control theory states that takeover is an efficient means to replace inefficient managers of the target companies. The target firm may under-perform either because its managers pursue their own interests at the expense of owners' interests or because they lack the knowledge and skills to maximize firm value. If managers of acquiring firms are more capable than those of acquired firms, they can improve the efficiency of the target companies. This theory predicts that poorly performing firms are more likely to be acquired and that the performance of target companies will improve after the takeover. Acquiring firms are also expected to gain from the takeover activity if they have the ability to bring operating synergy to the post-takeover entity.

\section{Managerial hubris and M\&As [14}

According to the managerial hubris hypothesis, even if managers try to maximize the value of the firm, they might overestimate the value of what they buy because of hubris. This is particularly true in waves of consolidation, when managers blindly follow the markets and change their beliefs on conglomeration versus strategic focus or when multiple bidders compete for the same target. Managers also could underestimate the cost of post-merger integration or overestimate their ability to control a larger institution. Thus, a transaction that is believed to benefit the acquirer could simply be a poor strategic decision where benefits are overestimated or costs are underestimated.

The results of an empirical article[15] suggest that both CEO overconfidence and CEO dominance are important in explaining the decision to acquire another firm. CEO dominance is particularly important in the case of diversifying acquisitions, with the probability of a diversifying acquisition almost doubling with a $10 \%$ increase in CEO dominance.

A higher proportion of independent directors on the board mitigates the effect of CEO overconfidence and CEO dominance and reduces the probability of the firm deciding to make an acquisition. If the effect of CEO overconfidence in making potentially value-destroying acquisitions is a concern to stockholders and corporate regulators, then the findings suggest that a possible solution may be to ensure that there is an independent board of directors.

The rationales for M\&As discussed above are not necessarily independent or mutually exclusive. In many cases, different motivations work interactively to bring about an M\&A deal. Moreover, some hypotheses have similar implications for the effect of acquisitions on M\&A firms, and it can be difficult to disentangle them. However, the analysis does enable identification of whether M\&As are primarily value-enhancing, value-neutral, or value-reducing.

\section{M\&A World and Central European trends 16}

After an excessive decline from 2000 to 2003, the volume of cross-border M\&As increased on average between 2004 and 
2006 by 46 percent, and regarding the number of deals, it expanded by 15 percent, reflecting again strong global M\&A activity, however the figures still remain below the peak in 2000. The rise in the value of cross-border M\&As was largely fuelled by the growing strength of stock markets, and sustained increases in the asset values of enterprises. The number of mega deals also expanded, due to the increasing of the purchasing power of investors. If the value of the deals are taken into consideration, these transactions accounted for more than $60 \%$ of the total value of the M\&As. The rise is widespread between regions and between sectors too. In North America, the value of crossborder M\&A sales nearly doubled in 2006. The engine of the increase were several mega deals in natural resources sector.

In Europe, M\&A activity remained high in terms of both sales and purchases. The major fundamental expected to pave the way for growth is the long-awaited consolidation accelerated by the single market, common currency and removal of protective regulatory regimes. After these painful consolidation processes, the European companies started to intensify the collaboration both horizontally and vertically. The United Kingdom was the main target country for cross-border M\&As by strategic investors from continental Europe owing to the countries openness to M\&A activity. Not only West European investors play important role, but also investors from the fast growing emerging economies, China, India and the Russian Federation.

Taking a look at the source of financing of the deals, the low cost debt-financing and the high corporate profits worldwide played central role. For example, in large deals, including many in the mining and oil industries, cash is now the standard payment method, despite the share exchanging in the late 1990s. The increasing role of debt financing can partly be explained by the fact that the cost of equity capital remains significantly higher than the cost of debt financing, on the other hand the continuing strong M\&A activity can also be partly explained by the fact that the current M\&A boom has produced more corporate value for the acquiring companies than the previous one.

M\&A market Central Europe represents approximately $12 \%$ of the European market.

Fig. 1 and Fig. 2 show the development of the M\&A sales and purchases activity in six Central European countries, in Hungary, Czech Republic, Slovakia, Slovenia, Poland and Estonia [17]. In the early 1990s the sum of the M\&A sales remained below 2000 mn USD, largely originated from Hungary as front runner of the transaction and from Poland. As a result of the regulatory changes (see chapter 3.2.1.1) from 1995 showed an upward trend and in 2000 parallel with the record high value in the world reached the peak point at the level of $14000 \mathrm{mn}$ USD. After the significant fall in 2003 - from 14000 mn USD slumped under 4000 - the value of the M\&A sales mounted up to the level of $8000 \mathrm{mn}$ USD. Concerning the average level of the deals can be layed down as a fact that until 2000 the average deal value stand under $30 \mathrm{mn}$ USD, but from 1999 to 2003 rocketed up to $65 \mathrm{mn}$ USD. The falling back affected this indicator too, it falled back to the level of 22 and just after two years recovered again as a result of the higher increase in the value of the deals than the number.

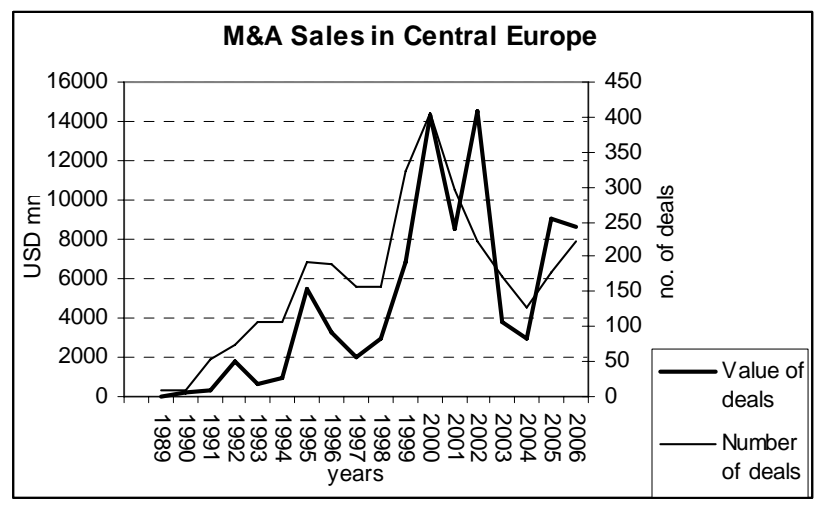

Fig. 1. (source of data: UNCTAD FDI database)

M\&A purchases of the studied countries started growing only after 1997 and reached the local peak in 2001 at 1600 mn USD. From 2002 to 2006 the value significantly increased and surpassed $3000 \mathrm{mn}$ USD. The average deal value is lower than in case of the M\&A sales. From 1993 to 2002 the level was under $20 \mathrm{mn}$ USD, but the previously mentioned upward trend went with 30 percent decrease in number of deals. This process indicates ascending concentration on the M\&A market in Central Europe.



Fig. 2. (source of data: UNCTAD FDI database)

In general it can be declared, that several deal and target characteristics significantly affect the method of payment choice. If we analyse the effect of the overmentioned low-cost debts as an engine in the financing of the mergers and acquisitions we can have the expectation that on a lower level of refinancing rates ceteris paribus - the time series data will show higher M\&A activity accordingly. In age of abundance of money companies can reach cheaper source of money and it would allow such mergers and acquisitons which previously were not economically rational to accomplish [18]. Obtaining money for the M\&A deals fundamentally depends on the actual refinancing rates. In this analysis the time series of the refinancing rates are compared to the level of the M\&A in case of six Central European countries. The interbank figures are from the Reuters Kobra information system, the M\&A data is based on UNCTAD FDI Database. By 


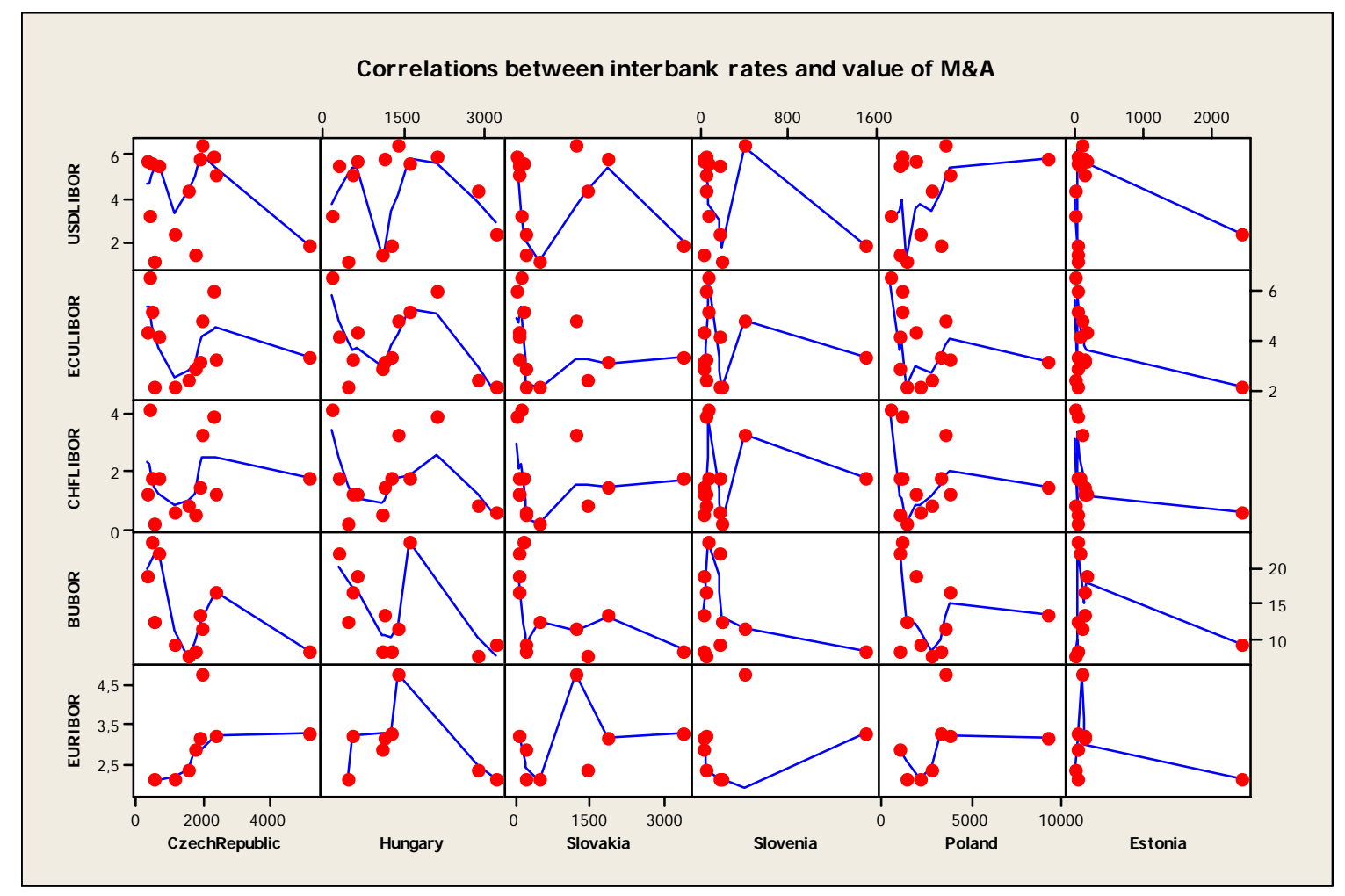

Fig. 3.

analysing the data - as the Fig. 3 illustrates - no significant correlations can be concluded between the two factors. The results suggest that in the Central European region the low-cost debt financing has not strong impact on the M\&A activity.

\section{M\&A data analysis for Hungary}

\subsection{Used data}

After reviewing the basic data the local composition of the M\&A was analysed. The used data is based on the ISI Emerging Markets DealWatch database, which contains detailed informations about 25000 mergers and acquisitions worldwide expressly in case of countries with emerging markets. Unfortunately the data from UNCTAD FDI Database and from ISI Emerging Markets database contain inconsistencies in many fields. It is a common phenomena pertaining to $\mathrm{M} \& \mathrm{~A}$ statistics that the reliability of the data is often doubtful. In case of cumulated data the UNCTAD database contains more exact figures, but does not include detailed values at deal and company level. In compliance with it in the followings for the detailed - deal level - analysis the ISI sample, for the comprehensive decomposition the UNCTAD data will be used.

The ISI Emerging Markets sample contains 125 acquisition deals where the target company was Hungarian, the net assets of the target company were higher than one million dollar and the value of the deal was higher than one million dollar. In accordance with the disposable data the observed period was from 2003 to 2008.

\subsection{M\&A in Hungary}

As the Fig. 4 shows the FDI Inflow and the level of M\&A strongly move together. This correlation is particularly conspicuous in case of the two peak points in 1995 and in 2005. The pearson correlation of the FDI Inflow and M\&A data is 0,77.

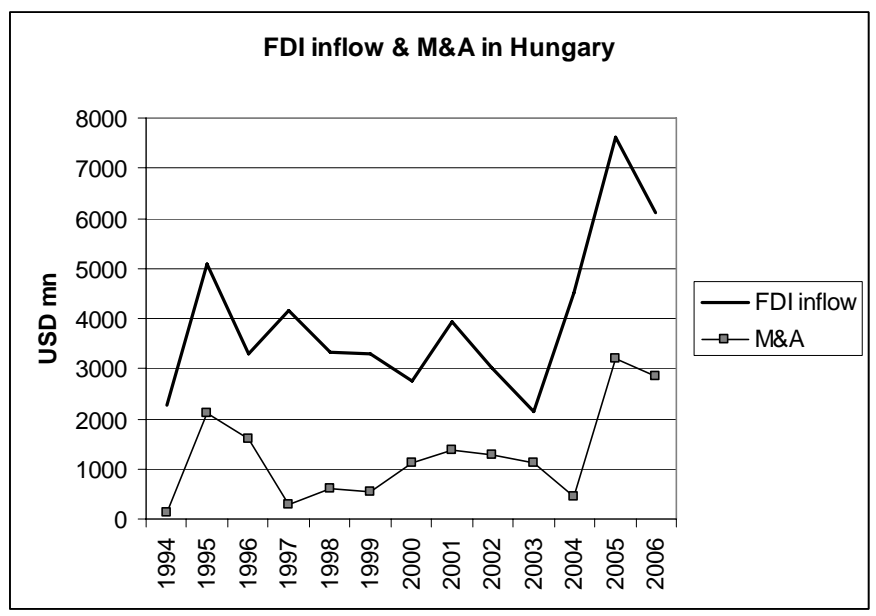

Fig. 4. M\&A and FDI in Hungary (source of data: UNCTAD)

Concerning the origination of the owners of the aquirer companies as shown in Table 1 shows that (based on the the ISI Emerging Markets database) the contractors are significantly contentrated. Companies from the first three countries give $60 \%$ of the whole quantity. This one sided investorial circle often can be observed in case of countries on half-periphery [19].

This high level of concentration is not only in case of origination demonstratable (Fig. 5) but also in case of the value of the deals. The top 10 deals of the sample represents $70 \%$ of the total 
Tab. 1. M\&A by origination of buyers (datasource ISI Emerging Markets DB)

\begin{tabular}{lc}
\hline $\begin{array}{l}\text { Country of the majority owners } \\
\text { of the forestaller company }\end{array}$ & deal value USD $\mathbf{~ n n}$ \\
\hline Germany & 6682 \\
Austria & 5174 \\
United Kingdom & 3679 \\
France & 1349 \\
Czech Republic & 1303 \\
Oman & 1276 \\
Belgium & 1217 \\
Norway & 870 \\
Switzerland & 819 \\
Mexico & 529 \\
United States & 508 \\
Ukraine & 470 \\
Russia & 442 \\
\hline
\end{tabular}

value of M\&A deals. One side the figures are conform with the theory which states that small firms - because of they are more vulnerable, the insolvency risk is higher, the growth prospects are relatively lower - many times are not so attractive for aquisitors. But if they can gain benefits from enonomy of scale, then these companies will be aims of aquisition (in accordance with chapter 3.2.1.3). The next 20 deals mean further $20 \%$. This is the reason why the goverment's FDI and M\&A policy can have high impact on the whole inflow-outflow process. It emphasizes the importance of the following two fields, first the system of the govermental subsidies, second the supporting institutions, ensuring the two-directional communication about special interests between companies and the goverment.

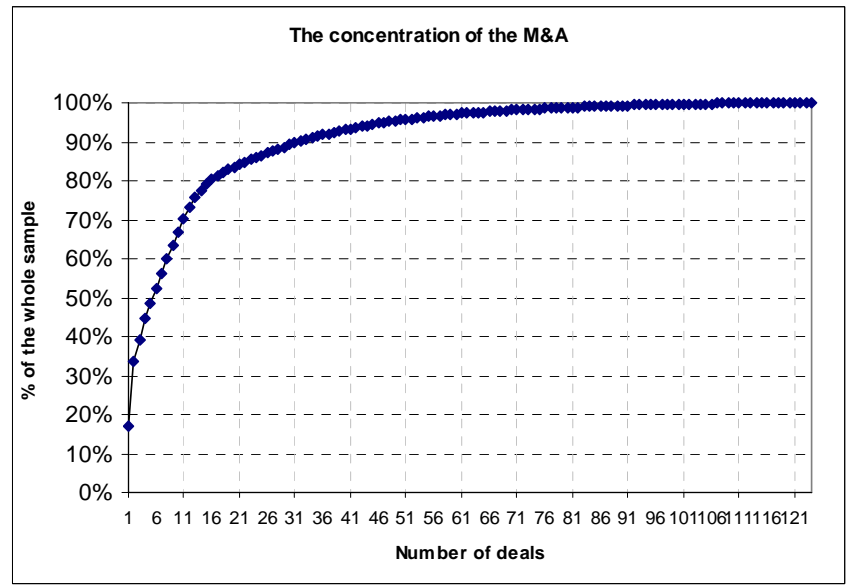

Fig. 5.

In the growth level the „mega-deals” have also a strong effect. Parallel with the world trends these deals were mostly made in natural resources, and natural resources refining sector, where economy of scale has key role in profitability (corresponding to chapter 3.2.2.1). This impact can be well demonstrated in 2005, when the average trend would be negative, but the two huge M\&A deal reversed the tendency into positive. The aver- age level of development fell back in summer of 2002. As Fig.6 shows the growth rate became more significant again only in the beginning of 2007. From this turning point on the M\&A acitvity and regained strength reached a new peak point in 2008 .

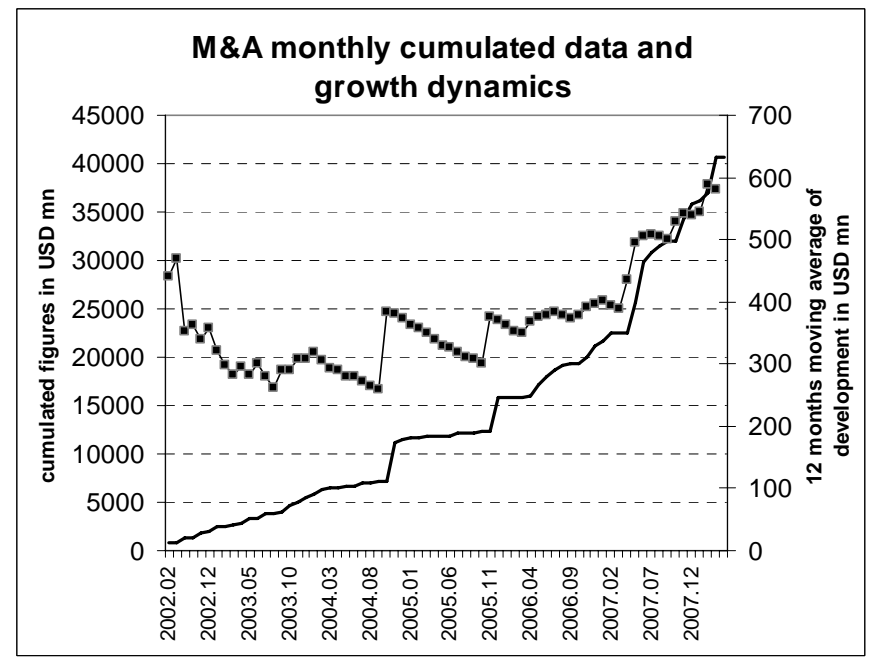

Fig. 6.

By analysing the composition of the deals by deal type (Fig. 7 Based on ISI classification) we found that more than $60 \%$ of all deals were simple acquisitions. Subsequent important categories are the privatisation and later the minority stake purchase. Buying up the still extant state property and acquire minority ownership in profitable sectors are more and more enticing for foreign companies. Recently block trades and privatisation trough stock exchange together mount up only $10 \%$ of the total value. Contrary to the 1990s after 2002 only marginal privatisation was carried out through stock exchange.



Fig. 7.

If we compare the average deal value to the own capital and the number of deals, two interesting trends are observable (Fig. 8). The first is that until 2005 the buyer companies get hold of majority stake in the buyed up companies from 2006 the events took a sharp turn and from an average level of $55 \%$ falled back to a $15-25 \%$. The second parallel trend was the decrease of the number of deals. 


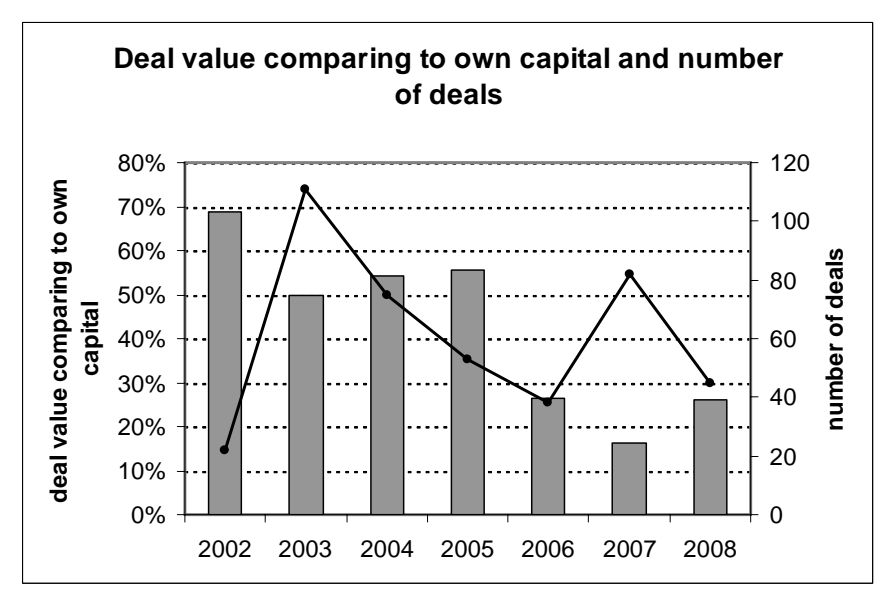

Fig. 8.

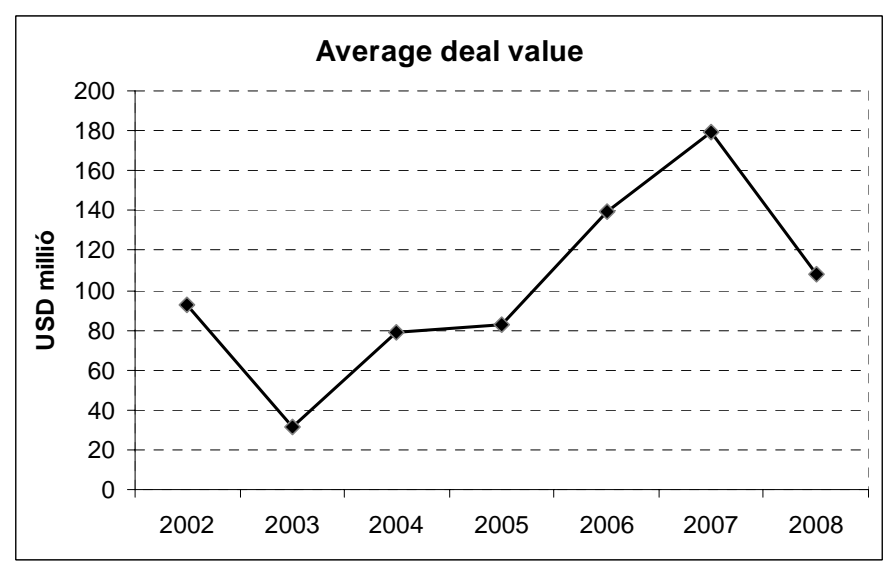

Fig. 9.

From this can be concluded that the target companies became the larger ones and the precipitously increase in the average deal value (Fig. 9) would predict that the ,mega-deals" will be the main determinants on the M\&A market in the following years in Hungary.

\section{Summary}

In this paper the M\&A trends in Hungary were explored. Using data from ISI Emerging Markets DB and UNCTAD FDI database the following characteristics are demonstrated. On international level the rise in the value of cross-border M\&As was largely fuelled by the growing strength of stock markets, and sustained increases in the asset values of enterprises. In CentralEurope increasing concentration was observable on the origin of aquiror's country level and on deal level.

In Hungary the first three „mega-aquisitions” give the twothirds of the total value of the deals. This one sided investorial circle are common in other Central-European countries too. Due to the high and steadily increasing concentration of the deals, the importance of the competition law and the role of the competition authority also becomes higher. On the one hand it should mean more intensive two-directional communication between companies, stakeholders and the goverments, on the other hand with strict regulation the evolution of monopol markets should be prevented.

\section{References}

1 Weston J F, Chung K S, Hoag S E, Mergers, restructuring, and corporate control, Prentice Hall, Englewood Cliffs, 1990.

2 Grant R M, On 'dominant logic', relatedness and the link between diversity and performance, Strategic Management Journal 9 (1988), no. 6, 639-642, DOI 10.1002/smj.4250090610.

3 Chatterjee S, Types of synergy and economic value: The impact of acquisition on merging and rival firms, Strategic Management Journal 7 (1986), no. 2, 119-139, DOI 10.1002/smj.4250070203.

4 Tóth K, Álom és valóság, 2004. PhD dissertation, BKAE.

5 Jensen Michael C., Agency costs of free cash flow, corporate finance, and takeovers, American Economic Review 76 (1986), 323-329. Papers and proceedings.

6 Jensen M C, Ruback R S, The market for corporate control: The scientific evidence, Journal of Financial Economics 11 (1983), 5-50, DOI 10.1016/0304-405X(83)90004-1.

7 Jensen M C, Takeovers: their causes and consequences, Journal of Economic Perspectives 2 (1988), 21-48.

8 Shleifer Andrei, Vishny Robert W, Takeovers in the '60s and the '80s: Evidence and implications, Strategic Management Journal 12 (1991), 49-59. Winter Special Issue.

9 J. David Cummins, Xiaoying Xie, Mergers and acquisitions in the US property-liability insurance industry: Productivity and efficiency effects, Journal of Banking \& Finance 32 (2008), 30-55. Issue 1, Dynamics of Insurance Markets: Structure, Conduct, and Performance in the 21st Century, January 2008,

10 UNCTAD: World Investment Report 2004, Geneva, 2004.

11 Stefano Rossi, Paolo F. Volpin, Cross-country determinants of mergers and acquisitions, Journal of Financial Economics 77 (2004), 277-304, DOI 10.1016/j.jfineco.2003.10.001.

12 Doukas J A, Investment decisions and internal capital markets: Evidence from acquisitions, Elsevier Bv. Amsterdam, 2007.

13 Jensen M C, Agency Costs of Free Cash Flow, Corporate Finance, and Takeovers, Papers and Proceedings of the Ninety-Eighth Annual Meeting of the American Economic Association, May, 1986, pp. 323-329.

14 Roll R, The Hubris Hypothesis of Corporate Takeovers (Part 1), The Journal of Business 59 (Apr., 1986), no. 2, 197-216, DOI 10.1086/296325, available at http://www . jstor.org/pss/2353017

15 Rayna Brown, Neal Sarma, CEO overconfidence, CEO dominance and corporate acquisitions, Journal of Economics and Business 59, 358-379, available at http://www.sciencedirect.com/science/article/ B6V7T-4NNOW9G-5/2/97d190773776b070c66cb44c1c58c8ea Ownership structure and corporate decision-making, September-October 2007.

16 UNCTAD: World Investment Report 2007, Geneva.

17 UNCTAD FDI Database, available at http://stats.unctad.org/fdi/ eng/ReportFolders/Rfview/Explorerp.asp?CS_referer

18 Faccio M, Masulis R W, The Choice of Payment Method in European Mergers and Acquisitions, The Journal of Finance 60 (2005), 1345-1388.

19 Kozma F, Félperiféria, Aula, Budapest, 1998. 